\title{
Potency of Botryococcus braunii cultivated on palm oil mill effluent wastewater as a source of biofuel
}

\author{
Muhamad Maulana Azimatun Nur ${ }^{1,2^{\dagger}}$, Tutik Muji Setyoningrum², I Gusti Suinarcana Budiaman² \\ 'Department of Chemical Engineering, Faculty of Industrial Technology, Universitas Pembangunan Nasional "Veteran" Yogyakarta. Jl. SWK 104, \\ Condongcatur, Sleman, Yogyakarta 55281, Indonesia \\ 2Department of Ocean Ecosystems, Energy and Sustainability Research Institute Groningen, University of Groningen, Nijenborgh 7, 9747 AG \\ Groningen, The Netherlands
}

\begin{abstract}
Indonesia is known as the largest oil palm producer in the world. However, along with the production, it generates wastes and pollution that caused the environmental problem in surrounding areas. Previous researchers reported that the high palm oil mill effluent (POME) concentration inhibited microalgae growth. However, the inhibition factor was not clearly explained by using kinetic model. This study presents kinetic models of Botryococcus braunii (B. braunii) cultivated on POME wastewater under different turbidity condition. Results showed that the growth model of Zwietering was closely suitable with experimental results. It was found that B. braunii was able to consume organic carbon from the POME wastewater on the logarithmic model. A modified kinetic model of Monod Haldane described the influence of turbidity and chemical oxygen demand on the cultivation. Turbidity of POME medium inhibited the growth rate at KI 3.578 and KII 179.472 NTU, respectively. The Lipid (39.9\%), and carbohydrate (41.03\%) were found in the biomass that could be utilized as biofuel source.
\end{abstract}

Keywords: Biofuel, Botryococcus braunii, Kinetic model, Palm oil mill effluent, Turbidity

\section{Introduction}

Food agricultural organization statistical database (FAOSTAT) from United Nation reported that South East Asia coconut palm oil (CPO) production shares $88.6 \%$ of total world production. Within this region, Indonesia is known as the largest producer, followed by Malaysia and Thailand [1]. From 2010 to 2014, the production increased with $30.14 \%$ [2]. In 2014, Indonesia CPO production was about 22,500,000 metric ton [3]. However, along with the production, it generates wastes and pollution that caused the environmental problem in surrounding areas. Palm oil mill effluent (POME) is a wastewater generated from CPO processing. It contains high nutrients, total suspended solid (TSS), and total dissolved solid (TDS). It is reported that the production of a ton of CPO will generate about 2.5-3.0 $\mathrm{m}^{3}$ of POME [4]. Releasing untreated POME directly to the surroundings will cause serious pollution problems in the environment due to high chemical oxygen demand (COD) and biological oxygen demand (BOD) content. In a traditional industry, $\mathrm{POME}$ is treated by conventional facultative anaerobic-aerobic open ponds to reduce the $\mathrm{COD}$ and $\mathrm{BOD}$ content. It requires a large area, and the release of the greenhouse gasses may harm the environment. Generally, high COD loading and low $\mathrm{pH}$ of the palm oil mill effluent, together with the colloidal nature of the total suspended solids, render treatments by conventional methods difficult [5].

Recently, there have been many discussions on the progress of wastewater reuse globally to protect the environment and achieve sustainable resources, as well as food, fuel, and feed products [6-10]. Microalgae could be a promising agent to lower agro-industrial wastewater due to the capability to utilize nutrient for the growth $[6,7]$. Several researchers reported the potential of POME as promoting media for microalgae growth $[8,9]$. Moreover, the wastewater can provide the mixotrophic mode for microalgae medium due to the content of organic carbon [11].

The biomass of Botryococcus braunii (B. braunii) is a potential source for biofuel due to the capability to produce a high amount of hydrocarbon and could be converted into several chemical products [12]. Based on our knowledge, the cultivation of $B$. braunii
This is an Open Access article distributed under the terms of the Creative Commons Attribution Non-Commercial License (http://creativecommons.org/licenses/by-nc/3.0/) which permits unrestricted non-commercial use, distribution, and reproduction in any medium, provided the original work is properly cited.
Received May 1, 2017 Accepted June 18, 2017

${ }^{\dagger}$ Corresponding author

Email: m.m.azimatun.nur@rug.nl

Tel: +62-274-486733 Fax: +62-274-486733 
on POME wastewater was not well explored. Kamyab et al. [13] reported that the high POME concentration inhibited microalgae growth. However, the inhibition factor was not clearly explained by using the kinetic models.

Previous researchers reported the kinetic study of microalgae cultivated on wastewater to produce biofuel source. Silva et al. [14] evaluated the kinetics of biomass production and nutrient removal by two microalgal species cultivated on synthetic wastewater by using pseudo-first-order kinetic model. While Gani et al. [15] predicted the growth of Botryococcus sp. and the nutrient uptake on domestic wastewater by using Logistic model. However, both kinetic models are not proposed to predict the growth of algae on wastewater contained high turbidity. Focus of this research was to study the influence of turbidity on the kinetic model of $B$. braunii cultivated on the different POME concentration and comparing both of the kinetic models. Focus of this research was to study the influence of turbidity on the kinetic model of $B$. braunii cultivated on different digested POME concentration.

\section{Materials and Methods}

\subsection{Wastewater Preparation}

The POME was collected from an anaerobic ponding system of traditional palm oil mill industry in Lampung, Sumatra. POME was pretreated by heating at $80^{\circ} \mathrm{C}$ atmospheric pressure to prevent bacteria contamination. The preparation was followed by using 400 mesh filter cloth to decrease the suspended solid. The initial COD of digested POME was 1,200 mg/L, $400 \mathrm{mg} / \mathrm{L} \mathrm{N}$-total, 280 $\mathrm{mg} / \mathrm{L}$ ammonia, $\mathrm{P}$ as $\mathrm{PO}_{4}^{-} 20 \mathrm{mg} / \mathrm{L}$, TSS $250 \mathrm{mg} / \mathrm{L}$, and $\mathrm{pH} 8.5$.

\subsection{Cultivation Condition and Measurement}

$B$. braunii strain was purchased from central institute of brackish water aquaculture BBPBAP Jepara, Central Java. B. braunii was inoculated in a modified Chu 13 medium [16], which $\mathrm{KNO}_{3}$ was replaced with urea, and $\mathrm{KH}_{2} \mathrm{PO}_{4}$ was replaced by triple super phosphate. For experimental data, digested POME wastewater was diluted with double distilled water at different ratio $0-50 \% \mathrm{v} / \mathrm{v}$. Control as modified Chu 13 was added with $1 \mathrm{~g} / \mathrm{L} \mathrm{NaHCO}_{3}$ as an inorganic carbon source to compare the autotrophic and mixotrophic condition of algae cultivated on POME. Cultivation was carried out in 2 L Erlenmeyer flask with working volume $80 \%$ volume and gently mixed with aerator at $0.5 \mathrm{vvm}$ containing sterile air. Fluorescent lamp was employed as the source of light at 5,000 lux intensity. Temperature, salinity, and $\mathrm{pH}$ were set at $28^{\circ} \mathrm{C}, 0.15$ $\mathrm{M} \mathrm{NaCl}$, and 6.8-7.2, respectively.

$$
\operatorname{Dry} \operatorname{biomass}(X, g / L)=\left(O D_{680}-0.0495\right) / 1.0089
$$

The cultivation was measured daily by using spectrophotometer optima SP-300 to obtain optical density at $680 \mathrm{~nm}$ wavelength $\left(\mathrm{OD}_{680}\right)$ of the cell. The wavelength has advantage to facilitate the prediction of the biomass at low concentration in wastewater and cloudy water as reported by Alvares-Diaz et al. [17] and Myers et al. [18]. The initial media without the addition of microalgae cells was used as a blank. Dry biomass $(X, \mathrm{~g} / \mathrm{L})$ was recorded by plotting the results of OD to Eq. (1) [17]. Specific growth rate was calculated from Eq. (2) [8].

$$
\mu=\frac{\ln \left(O D_{t}-\ln \left(O D_{0}\right)\right.}{t_{t}-t_{0}}
$$

where $O D_{t}$ (unitless) is the optical density of the cell at the end of exponential time ( $t_{t}, \mathrm{~d}$ ), $O D_{0}$ (unitless) is the optical density of the cell at the beginning of cultivation time $\left(t_{0}, \mathrm{~d}\right)$. COD was measured using SNI protocol No. 06-6989.22-2004 [19], each day for $6 \mathrm{~d}$.

\subsection{Modeling Method}

To investigate the growth kinetics of $B$. braunii, models were investigated by measuring the growth rate, the substrate consumption rate, and the effect of substrate on the growth rate. Parameters of these models were predicted by using Minitab 16.0 software. The growth result of $B$. braunii cultivated on different POME concentration was employed to validate the models.

\section{B. braunii growth model}

Many growth kinetic models such logistic, Gompertz, Schnute, Baranyi-Roberts, and Monod are available for predicting the growth of microalgae. The logistic model by Bailley and Ollis [20] was widely applied for the cell growth. It uses the simple calculation to study the microbial growth due to independent of substrate consumption [21]. The model provides the specific growth, the initial cell concentration, and the maximum cell concentration as

$$
X_{t}=\frac{X_{0} \cdot e^{\mu . t}}{1-\left(\frac{X_{0}}{X_{s}} \cdot\left(1-e^{\mu . t}\right)\right)}
$$

where $X_{t}(\mathrm{~g} / \mathrm{L})$ is the concentration of $B$. braunii cell at any time $t(\mathrm{~d}), \mu\left(\mathrm{d}^{-1}\right)$ is specific growth rate, $X_{0}(\mathrm{~g} / \mathrm{L})$ is the concentration of the cell at the beginning of cultivation, and $X_{s}(\mathrm{~g} / \mathrm{L})$ is the maximum concentration of the cell.

Zwietering model was employed for the cultivation of algae and bacteria on the wastewater medium [22-25]. Zwietering model provides the lag phase time, specific growth, initial cell concentration, and maximum cell concentration. It was modified from Gompertz [25] as

$$
X_{t}=X_{s} \cdot \exp \left\{-\exp \left[\frac{\mu \cdot e}{X_{s}}(\lambda-t)+1\right]\right\}
$$

where $x_{t}(\mathrm{~g} / \mathrm{L})$ is the concentration of the cell at any time $t(\mathrm{~d})$, $\mu\left(\mathrm{d}^{-1}\right)$ is specific growth rate, $X_{s}(\mathrm{~g} / \mathrm{L})$ is the maximum concentration of the cell, and $\lambda$ is lag time (d).

Monod kinetic model was employed to evaluate the growth related to the substrate consumption. Monod [26] equation is the well-known model to describe the relation of the growth with the substrate utilization.

In order to evaluate the growth rate related to the turbidity, the model was described as

$$
\mu=f(S) .(I)
$$


The growth rate $(\mu)$ was influenced by a substrate $(S)$ and intensity (I) [27-29]. The modified model was proposed as

$$
\mu=\frac{\mu_{\max } \cdot S}{K_{s}+S+\left(\frac{S^{2}}{K_{i}}\right)} \cdot \frac{K \cdot I}{K_{I}+I+\frac{I^{2}}{K_{I I}}}
$$

where $I$ (lux) is light intensity, $K_{I}$ and $K_{I I}$ are saturation and inhibition constant (lux), and $K$ is constant. The light intensity was substituted by the turbidity by using modified Beer Lambert law in Eq. (7) and Eq. (8) [30].

$$
\begin{gathered}
\log \left(\frac{I_{\text {in }}}{I_{\text {out }}}\right)=k \cdot X_{0} \cdot Z_{\max } \\
I_{\text {out }}=I_{\text {in }} \exp \left[\left(-k \cdot X_{0}\right)+k_{\text {bg }}\right] \cdot Z_{\max }
\end{gathered}
$$

where $I_{\text {out }}$ is outgoing light (lux), $I_{\text {in }}$ is incoming light (lux), $X_{o}$ is initial cell concentration of the algae, $k$ is specific light constant, $k_{b g}$ is turbidity (NTU), and $Z_{\max }$ is mixing depth. At the beginning of the cultivation, $X_{o}$ was low, and $Z_{\max }$ was set to constant, thus Eq. (8) was simplified to Eq. (9).

$$
I_{\text {out }}=I_{\text {in }} \exp ^{k_{b g}}
$$

Since $I_{\text {out }}$ is equivalent to $K_{b g}$, the increasing of turbidity $K_{b g}$ will lower the incoming light intensity $\left(1 / I_{i n}\right)$. The correlation between Initial turbidity $K_{b g}$ and total suspended solid TSS (mg/L) was calculated from Eq. (10) [31]

$$
K_{b g}=0.4833(T S S)^{1.012}
$$

Thus, Eq. (6) was modified as

$$
\mu=\frac{\mu_{\max } \cdot S}{K_{s}+S+\left(\frac{S^{2}}{K_{i}}\right)} \cdot \frac{K \cdot K_{b g}}{K_{I}+K_{b g}+\frac{K_{b g}{ }^{2}}{K_{I I}}}
$$

substrate consumption rate

Several substrate consumption kinetic models are available such Monod, zero order, first order, logarithmic, and logistic model [32] In this research, the first order (Eq. (12)) and the logarithmic kinetic model (Eq. (13)) were evaluated and compared to the substrate consumption rate in integral mode.

$$
\begin{gathered}
S=S_{0} \exp (-k \cdot t) \\
S=S_{0}+X_{0}[1-\exp (k \cdot t)]
\end{gathered}
$$

where $S(\mathrm{mg} / \mathrm{L})$ is the substrate calculated from the COD of POME at any time (t, d), $S_{0}$ is the initial substrate concentration (mg/L), and $k$ is the constant rate $\left(\mathrm{d}^{-1}\right)$.

\subsection{Component Analysis}

The lipid and carbohydrate content were evaluated by performing microwave-assisted extraction and acid hydrolysis. One hundred miligram of dry biomass sample was placed in a modified microwave equipped with a three neck flask and condenser. Modified Folch method was employed for the lipid extraction by using chloroform and methanol as co-solvent [33]. The sample was then extracted by using microwave irradiance at $30 \%$ power (max output 900 $\mathrm{W}, 2,450 \mathrm{Mhz}$ ) for $5 \mathrm{~min}$. The sample was extracted again by a conventional heating at $60^{\circ} \mathrm{C}$ and gently mixed for $30 \mathrm{~min}$ at $100 \mathrm{rpm}$. It was cooled and centrifuged at 1,000 rpm for $20 \mathrm{~min}$ to separate residue, chloroform, lipid, and methanol. At the center of layers, chloroform containing the lipid was gently pipetted out. And the chloroform was evaporated until the lipid reached a constant weight.

Acid hydrolysis was employed for carbohydrate analysis. The suspension of dried algae in water $(0.1 \mathrm{~g} / 10 \mathrm{~mL}$ or $10 \% \mathrm{w} / \mathrm{v})$ was mixed at $100 \mathrm{rpm}$ stirrer bar to homogenize the suspension. The liquid of $\mathrm{H}_{2} \mathrm{SO}_{4} 1.1 \% \mathrm{v} / \mathrm{v}$ was added to the sample as the catalyst. The mixture was processed in $70 \%$ power (equal to $630 \mathrm{~W}$ ) with frequency 2,450 Mhz and output $900 \mathrm{~W}$ for $8 \mathrm{~min}$. Phenol-sulfuric acid by Dubois et al. [34] was employed to analyze the total carbohydrate.

In order to analyze the lipid profile, GC/MS was employed. The lipid was converted into fatty acid methyl ester (FAME) as described by Martinez-Guerra et al. [35]. Further analysis was employed by using GC/MS (QP-2010 Shimadzu, Japan) equipped with silica capillary column ( $30 \mathrm{~m} 0.25 \mathrm{~mm}, 25 \mu \mathrm{m}$ ) and run at the flow rate of $1 \mathrm{~mL} / \mathrm{min}$. Helium was used as the carrier. The FAME was diluted with pure n- hexane before injected into the column. The protocol by Sahu et al. [36] was followed by next step.

\subsection{Statistical Analysis}

Minitab 16.0. (USA) was employed to predict parameters. Levenberg-Marquardt algorithm was used to minimizes the sums of the square and residuals between the predicted and the experimental results with the confidence level for regression coefficient $\mathrm{R}^{2}>95 \%$.

$$
\text { Sum of } \operatorname{error}(\%)=\frac{\text { experiment }- \text { predicted }}{\text { experiment }} \times 100 \%
$$

The sum of error (SE, \%) in Eq. (14) was performed to evaluate the error of predicted and experimental results.

Coefficient of determination $\left(\mathrm{r}^{2}\right)$ and index of agreement (d-index) were estimated to evaluate the performance of the models and the agreement of the values. The $\mathrm{r}^{2}$ and d-index value were ranged between 0 and 1 . The closer value to 1 means perfect model performance and perfect agreement between observed and predicted value $[37,38]$.

\section{Results and Discussion}

\subsection{Cell Growth on POME Medium}

Fig. 1 describes the growth profiles of $B$. braunii cultivated on various media. It indicated that the control containing modified Chu 13 was the most suitable media for $B$. braunii. When $B$. braunii 
was cultivated on POME, the growth rate was lower. The highest Napierian logarithm $\left(\ln \mathrm{X} / \mathrm{X}_{0}\right)$ was recorded for the control, followed by $5,3,7,10,30$ and $50 \%$ POME concentration. In this result, the optimum growth of $B$. braunii supplemented with POME was recorded at $5 \% \mathrm{v} / \mathrm{v}$ concentration. This condition was in line with Hadiyanto and Azimatun Nur [39] and Kamyab et al. [13] who cultivated microalgae in media containing different POME concentration.

It is reported that POME influenced growth due to the condition that generated the mixotrophic cultivation condition and provided organic carbon. However, POME also contains high turbidity that inhibits light penetration and acts as auto-inhibitor. According

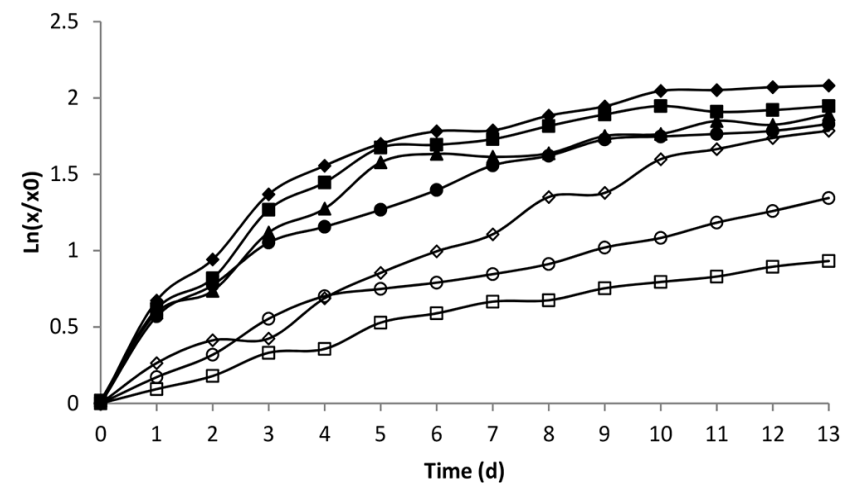

Fig. 1. Growth profile of $B$. braunii cultivated under different media; control $(\bullet), 3 \%(\mathbf{\Delta}), 5 \%(\boldsymbol{\square}), 7 \%(\boldsymbol{O}), 10 \%(\diamond), 30 \% \operatorname{POME}(\bigcirc)$, 50\% POME ( $\square$ ). to Budiman et al., the use of undiluted POME as a substrate inhibited the growth of phototrophs, such as Rhodobacter sphaeroides, due to the decrease of light penetration into the fermentation system [40]. In our result, the concentration of POME more than 50\% $\mathrm{v} / \mathrm{v}$ gave a negative result for the growth (data was not shown). The concentration of 10 to $50 \% \mathrm{v} / \mathrm{v}$ POME was employed for further investigation.

\subsection{Cell Growth Kinetic}

Fig. 2 shows the kinetic growth of $B$. braunii on different media. The Zwietering and the logistic kinetic model were suitable for the growth $\left(R^{2}>95 \%\right.$ ) (Table 1). The most suitable kinetic model for the growth was found on the Zwietering model with high average $\mathrm{r}^{2}$ of predicted and observed value. In Addition, the average of $\mathrm{d}$-value on Zwietering model was also higher, indicating that the model gave better agreement value compared to Logistic model (Table 2 and 3). In the model, the value of lag phase time was included. By this condition, the Zwietering model was more suitable for ideal cultivation condition that consists of lag, log, and stationary phase. It is proved that the lag phase time is important during the acclimatization of algae on wastewater medium and should be included on the model.

However, when the high POME was added (400 mg/L), both of the models gave poor $\mathrm{r}^{2}$ and $\mathrm{d}$-value. It seems that other disturbances were influenced on the growth such as turbidity content that could inhibit the growth, resulting inaccuracy of the models.
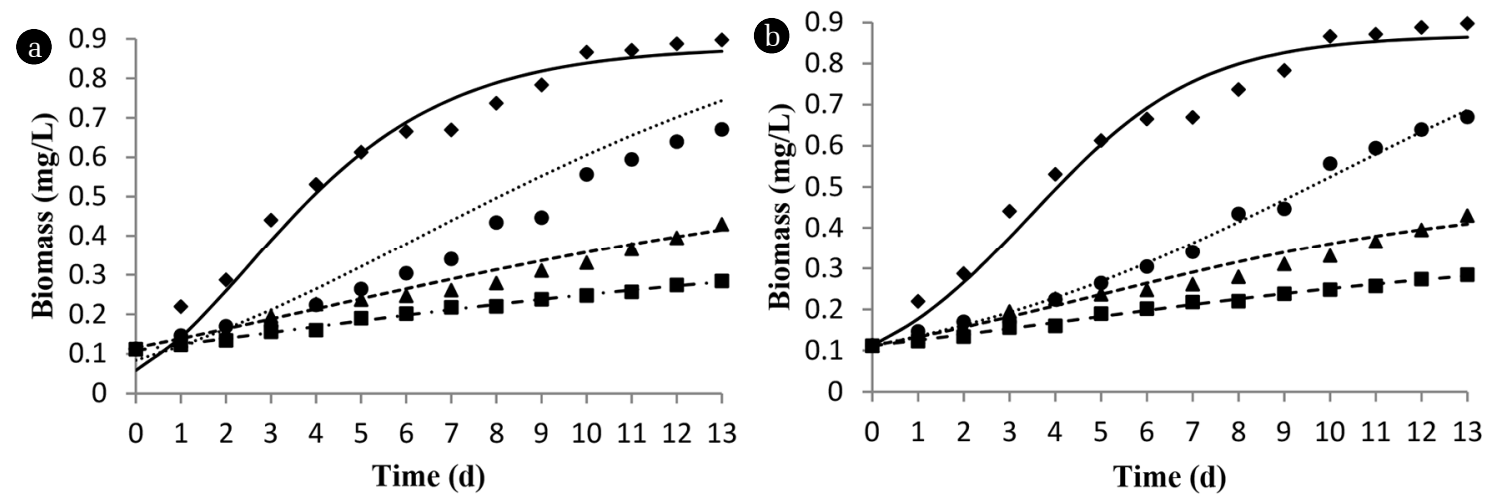

Fig. 2. Growth profile of (a) logistic and (b) Zwietering for the effect of different media; data experiment of control (modified Chu 13) (u), $130 \mathrm{mg} / \mathrm{L}$ COD (10\% POME) (O), $250 \mathrm{mg} / \mathrm{L}$ COD (20\% POME) (p), $400 \mathrm{mg} / \mathrm{L} \mathrm{COD} \mathrm{(30 \%} \mathrm{POME)} \mathrm{(n);} \mathrm{simulated} \mathrm{result} \mathrm{of} \mathrm{control}$

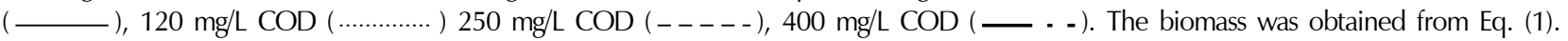

Table 1. Parameters for Cell Growth Models

\begin{tabular}{|c|c|c|c|c|c|c|c|c|c|}
\hline \multirow{2}{*}{ Media } & \multicolumn{4}{|c|}{ Zwietering model } & \multicolumn{3}{|c|}{ Logistic model } & \multicolumn{2}{|c|}{ Observed value } \\
\hline & $\mathbf{X}_{\mathrm{s}}$ & $\lambda$ & $\mu_{\max }$ & $\mathbf{R}^{2}$ & $\mathbf{X}_{\mathrm{s}}$ & $\mu_{\max }$ & $\mathbf{R}^{2}$ & $\mathbf{X}_{\mathrm{s}}$ & $\mu_{\max }$ \\
\hline Control & 0.825 & 0 & 0.129 & 0.982 & 0.803 & 0.543 & 0.998 & 0.840 & 0.159 \\
\hline COD $130 \mathrm{mg} / \mathrm{L}$ & 0.679 & -3.42 & 0.044 & 0.981 & 0.615 & 0.329 & 0.964 & 0.670 & 0.137 \\
\hline COD $250 \mathrm{mg} / \mathrm{L}$ & 0.528 & -4.303 & 0.025 & 0.975 & 0.417 & 0.234 & 0.966 & 0.429 & 0.103 \\
\hline COD $400 \mathrm{mg} / \mathrm{L}$ & 0.338 & -7.194 & 0.012 & 0.974 & 0.292 & 0.127 & 0.973 & 0.284 & 0.071 \\
\hline
\end{tabular}


Table 2. Estimated Parameter of $\mathrm{R}^{2}$ and $\mathrm{d}$-index between Observed Optical Density $\left(\mathrm{OD}_{\mathrm{e}}\right)$ and Predicted Optical Density $\left(\mathrm{OD}_{\mathrm{p}}\right)$ on Logistic Model at Different Media

\begin{tabular}{|c|c|c|c|c|c|c|c|c|c|c|c|c|c|c|c|}
\hline \multicolumn{4}{|c|}{ Control } & \multicolumn{4}{|c|}{ COD $130 \mathrm{mg} / \mathrm{L}$} & \multicolumn{4}{|c|}{ COD $250 \mathrm{mg} / \mathrm{L}$} & \multicolumn{4}{|c|}{$400 \mathrm{mg} / \mathrm{L}$} \\
\hline $\mathrm{OD}_{\mathrm{e}}$ & $\mathrm{OD}_{\mathrm{p}}$ & $\mathbf{r}^{2}$ & d & $\mathrm{OD}_{\mathrm{e}}$ & $\mathrm{OD}_{\mathrm{p}}$ & $\mathbf{r}^{2}$ & d & $\mathrm{OD}_{\mathrm{e}}$ & $\mathrm{OD}_{\mathrm{p}}$ & $\mathbf{r}^{2}$ & d & $\mathrm{OD}_{\mathrm{e}}$ & $\mathrm{OD}_{\mathrm{p}}$ & $\mathbf{r}^{2}$ & d \\
\hline 0.113 & 0.058 & 0.991 & 0.949 & 0.113 & 0.084 & 0.991 & 0.927 & 0.112 & 0.115 & 1.000 & 0.967 & 0.112 & 0.109 & 0.999 & 0.907 \\
\hline 0.220 & 0.142 & 0.974 & 0.891 & 0.147 & 0.120 & 0.990 & 0.913 & 0.133 & 0.138 & 0.998 & 0.927 & 0.133 & 0.124 & 0.981 & 0.562 \\
\hline 0.288 & 0.259 & 0.994 & 0.935 & 0.170 & 0.162 & 0.999 & 0.968 & 0.154 & 0.163 & 0.994 & 0.830 & 0.144 & 0.139 & 0.991 & 0.631 \\
\hline 0.441 & 0.388 & 0.947 & 0.629 & 0.172 & 0.211 & 0.973 & 0.795 & 0.195 & 0.188 & 0.992 & 0.730 & 0.165 & 0.154 & 0.000 & 0.000 \\
\hline 0.531 & 0.508 & 0.957 & 0.171 & 0.224 & 0.264 & 0.952 & 0.630 & 0.226 & 0.214 & 0.928 & 0.000 & 0.176 & 0.169 & 0.000 & 0.000 \\
\hline 0.613 & 0.610 & 0.764 & 0.000 & 0.265 & 0.321 & 0.848 & 0.000 & 0.237 & 0.239 & 0.996 & 0.506 & 0.197 & 0.184 & 0.000 & 0.000 \\
\hline 0.686 & 0.688 & 0.998 & 0.903 & 0.305 & 0.380 & 0.489 & 0.000 & 0.265 & 0.265 & 0.997 & 0.000 & 0.207 & 0.198 & 0.000 & 0.000 \\
\hline 0.700 & 0.747 & 0.871 & 0.205 & 0.364 & 0.438 & 0.000 & 0.000 & 0.291 & 0.289 & 0.000 & 0.000 & 0.231 & 0.212 & 0.586 & 0.000 \\
\hline 0.737 & 0.789 & 0.910 & 0.499 & 0.414 & 0.496 & 0.000 & 0.000 & 0.309 & 0.313 & 0.000 & 0.298 & 0.259 & 0.225 & 0.658 & 0.000 \\
\hline 0.784 & 0.818 & 0.970 & 0.780 & 0.457 & 0.552 & 0.000 & 0.000 & 0.311 & 0.336 & 0.568 & 0.000 & 0.211 & 0.238 & 0.559 & 0.000 \\
\hline 0.867 & 0.839 & 0.984 & 0.889 & 0.557 & 0.605 & 0.889 & 0.584 & 0.331 & 0.358 & 0.792 & 0.000 & 0.231 & 0.250 & 0.611 & 0.000 \\
\hline 0.872 & 0.853 & 0.994 & 0.930 & 0.595 & 0.655 & 0.892 & 0.672 & 0.366 & 0.378 & 0.982 & 0.687 & 0.246 & 0.262 & 0.599 & 0.000 \\
\hline 0.888 & 0.862 & 0.989 & 0.913 & 0.640 & 0.701 & 0.928 & 0.773 & 0.395 & 0.397 & 1.000 & 0.957 & 0.255 & 0.272 & 0.600 & 0.000 \\
\hline 0.898 & 0.868 & 0.987 & 0.908 & 0.671 & 0.744 & 0.921 & 0.793 & 0.430 & 0.415 & 0.991 & 0.838 & 0.260 & 0.282 & 0.864 & 0.000 \\
\hline \multicolumn{2}{|c|}{ Average } & 0.952 & 0.686 & & & 0.705 & 0.504 & & & 0.803 & 0.482 & & & 0.532 & 0.150 \\
\hline
\end{tabular}

Table 3. Estimated Parameter of $R^{2}$ and d-index between Observed Dry Weight $\left(D W_{e}\right)$ and Predicted Dry Weight $\left(D W_{p}\right)$ Calculated from Optical Density on Zwietering Model at Different Media

\begin{tabular}{|c|c|c|c|c|c|c|c|c|c|c|c|c|c|c|c|}
\hline \multicolumn{4}{|c|}{ Control } & \multicolumn{4}{|c|}{ COD $130 \mathrm{mg} / \mathrm{L}$} & \multicolumn{4}{|c|}{ COD $250 \mathrm{mg} / \mathrm{L}$} & \multicolumn{4}{|c|}{$400 \mathrm{mg} / \mathrm{L}$} \\
\hline $\mathbf{D W}_{\mathbf{e}}$ & $\mathrm{DW}_{\mathrm{p}}$ & $\mathbf{r}^{2}$ & d & $\mathbf{D W}_{\mathrm{e}}$ & $\mathbf{D W}_{\mathrm{p}}$ & $\mathbf{r}^{2}$ & d & DW $_{\mathrm{e}}$ & $O D_{p}$ & $\mathbf{r}^{2}$ & d & DW $_{\mathbf{e}}$ & $\mathbf{D W}_{\mathbf{p}}$ & $\mathbf{r}^{2}$ & d \\
\hline 0.113 & 0.112 & 1.000 & 0.947 & 0.113 & 0.113 & 1.000 & 0.955 & 0.112 & 0.112 & 1.000 & 0.990 & 0.112 & 0.112 & 1.000 & 0.966 \\
\hline 0.220 & 0.177 & 0.988 & 0.913 & 0.147 & 0.147 & 0.998 & 0.953 & 0.133 & 0.133 & 1.000 & 0.980 & 0.133 & 0.125 & 0.987 & 0.878 \\
\hline 0.288 & 0.266 & 0.996 & 0.959 & 0.170 & 0.170 & 0.999 & 0.985 & 0.154 & 0.157 & 0.999 & 0.961 & 0.144 & 0.139 & 0.993 & 0.915 \\
\hline 0.441 & 0.376 & 0.842 & 0.881 & 0.172 & 0.172 & 0.992 & 0.906 & 0.195 & 0.182 & 0.973 & 0.960 & 0.165 & 0.157 & 0.900 & 0.765 \\
\hline 0.531 & 0.494 & 0.730 & 0.888 & 0.224 & 0.224 & 0.999 & 0.876 & 0.226 & 0.209 & 0.865 & 0.898 & 0.176 & 0.168 & 0.904 & 0.781 \\
\hline 0.613 & 0.603 & 0.191 & 0.587 & 0.265 & 0.265 & 0.999 & 0.753 & 0.237 & 0.237 & 1.000 & 0.967 & 0.197 & 0.183 & 0.000 & 0.262 \\
\hline 0.686 & 0.692 & 0.994 & 0.984 & 0.305 & 0.305 & 0.993 & 0.405 & 0.265 & 0.264 & 0.986 & 0.976 & 0.207 & 0.196 & 0.000 & 0.000 \\
\hline 0.700 & 0.756 & 0.673 & 0.843 & 0.364 & 0.364 & 0.999 & 0.019 & 0.291 & 0.291 & 1.000 & 0.955 & 0.211 & 0.212 & 0.581 & 0.000 \\
\hline 0.737 & 0.799 & 0.788 & 0.865 & 0.414 & 0.414 & 0.987 & 0.089 & 0.309 & 0.316 & 0.961 & 0.950 & 0.219 & 0.225 & 0.662 & 0.000 \\
\hline 0.784 & 0.826 & 0.944 & 0.921 & 0.457 & 0.457 & 0.937 & 0.524 & 0.311 & 0.340 & 0.441 & 0.807 & 0.231 & 0.238 & 0.563 & 0.000 \\
\hline 0.867 & 0.843 & 0.992 & 0.942 & 0.557 & 0.557 & 0.951 & 0.842 & 0.331 & 0.361 & 0.745 & 0.846 & 0.241 & 0.251 & 0.616 & 0.000 \\
\hline 0.872 & 0.854 & 0.996 & 0.962 & 0.595 & 0.595 & 0.994 & 0.854 & 0.366 & 0.379 & 0.979 & 0.941 & 0.256 & 0.262 & 0.601 & 0.000 \\
\hline 0.888 & 0.860 & 0.990 & 0.950 & 0.640 & 0.640 & 0.999 & 0.880 & 0.395 & 0.396 & 1.000 & 0.989 & 0.265 & 0.272 & 0.598 & 0.000 \\
\hline \multirow[t]{2}{*}{0.898} & 0.864 & 0.987 & 0.945 & 0.671 & 0.671 & 0.996 & 0.880 & 0.430 & 0.409 & 0.983 & 0.948 & 0.270 & 0.281 & 0.859 & 0.000 \\
\hline & & 0.975 & 0.899 & & & 0.989 & 0.707 & & & 0.923 & 0.940 & & & 0.662 & 0.326 \\
\hline
\end{tabular}

\subsection{COD Consumption Rate}

Fig. 3 shows the COD consumption rate of $B$. braunii under different initial substrates. At the first day of the cultivation, the highest COD consumption rate was found in the initial COD $130 \mathrm{mg} / \mathrm{L}$, which decreased up to $47.84 \mathrm{mg} / \mathrm{L}$ in $6 \mathrm{~d}$. While at 250 and 400 $\mathrm{mg} / \mathrm{L}, B$. braunii was able to decrease the content up to 155 and
$282.93 \mathrm{mg} / \mathrm{L}$, respectively.

The highest reduction of COD value was also found at the initial COD $130 \mathrm{mg} / \mathrm{L}$. While the addition of POME decreased the COD efficiencies (Table 4). This is due to the effect of POME that acts as auto-inhibition substrate. In addition, the higher POME concentration generates cultivation mode from mixotrophic to slightly 


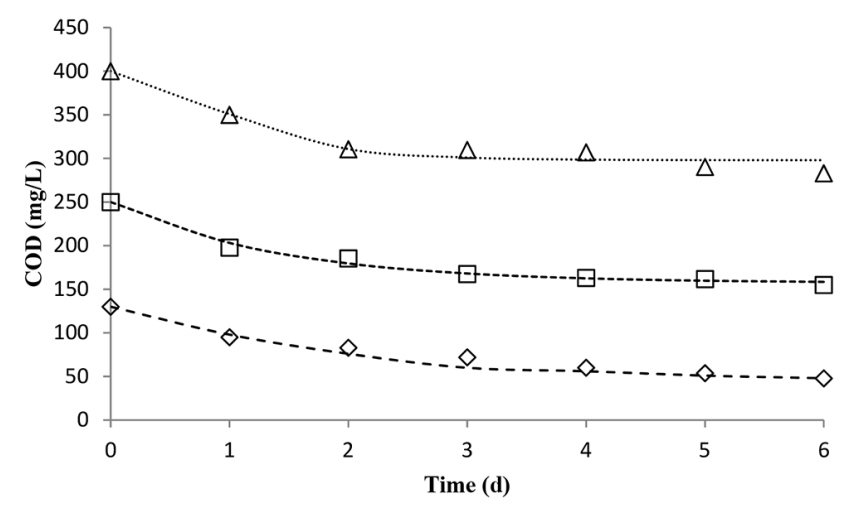

Fig. 3. COD consumption of $B$. braunii under different initial substrate from simulation of logarithmic model. $130 \mathrm{mg} / \mathrm{L} \mathrm{COD}(\diamond), 250$ $\mathrm{mg} / \mathrm{L}$ COD $(\square), 400 \mathrm{mg} / \mathrm{L} \mathrm{COD}(\Delta)$; simulated result of 400 $\mathrm{mg} / \mathrm{L}(\ldots \ldots \ldots \ldots \ldots . .),. 250 \mathrm{mg} / \mathrm{L} \mathrm{COD} \mathrm{(} \mathrm{-} \mathrm{-} \mathrm{-} \mathrm{-} \mathrm{),} 130 \mathrm{mg} / \mathrm{L}$ COD ( - - ) logarithmic kinetic model.

heterotrophic condition [11]. When the light was not provided in media, microalgae start consuming organic carbon as the source of energy in the heterotrophic condition. While in the mixotrophic condition, light and organic carbon can act as the dual energy source for algae, which is found on 130 and $250 \mathrm{mg} / \mathrm{L}$ COD of POME.

\subsection{Substrate Consumption Kinetic Model}

The logarithmic model was performed for the substrate consumption rate profile (Fig. 3). Table 4 shows that the high sum of error was found in the first order kinetic model. Simkins and Alexander [31] reported that the first order kinetic model was not suitable to predict the growth of microorganism that consumes high initial COD substrate. While the logarithmic kinetic model was suitable to predict in all ranges of initial substrates because of the initial biomass value is included into the equation. For the logarithmic kinetic rate, it is recorded at $0.451,0.320$, and 0.216 $\mathrm{d}^{-1}$ for 130,250 , and $400 \mathrm{mg} / \mathrm{L}$ of the COD, respectively. In our result, the highest COD efficiency was recorded from $130 \mathrm{mg} / \mathrm{L}$.

\subsection{COD Substrate - Growth Rate Kinetic Model}

Table 5 shows the result of parameters predicted by the Monod-Haldane and the modified Monod-Haldane kinetic model. Both kinetic models gave regression value $R^{2}>95 \%$. For Monod-Haldane model, the sum of error was $10.88 \%$, while modified Monod-Haldane was 6.01\%.

The simulation of the models was shown in Fig. 4. The Monod-Haldane model provides an explanation that the substrate can act as an inhibitor. For modified Monod-Haldane kinetic model, the turbidity value as the function of light intensity was included in the equation. For experimental results, the highest growth rate $\left(0.165 \mathrm{~d}^{-1}\right)$ was recorded at $75 \mathrm{mg} / \mathrm{L}$ COD. According to Fig. 4(b), the highest growth rate was $0.165 \mathrm{~d}^{-1}$ at $50 \mathrm{NTU}$ and $75 \mathrm{mg} / \mathrm{L}$ COD. While from Fig. 4(a), the model gave the highest growth rate at $0.161 \mathrm{~d}^{-1}$ when $75 \mathrm{mg} / \mathrm{L}$ substrate was added.

Table 6 shows the estimation of $\mathrm{R}^{2}$ and d-value of the models. The result explained that the $\mathrm{R}^{2}$ of the modified Monod-Haldane model gave better performance. In addition, the d-value was higher compared to Monod-Haldane model that described better results for the growth rate kinetic model under different POME concentration due to the turbidity value that was included in the model. It indicated that the COD was not only the inhibitor parameter for $B$. braunii growth, but also the turbidity content can act as inhibitor due to the low penetration of the light. In this model,
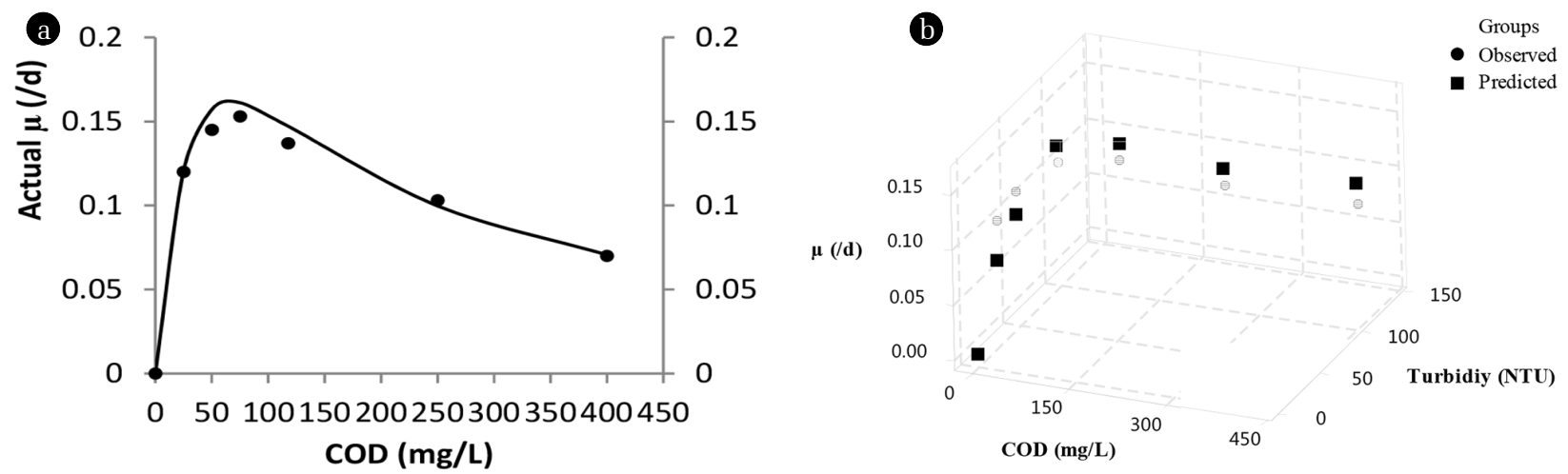

Fig. 4. Predicted $(\neg)$ and observed ( $)$ growth rate of Monod-Haldane kinetic model (a) and Modified Monod-Haldane kinetic model (b)

Table 4. Parameters for the Substrate Consumption Rate Models

\begin{tabular}{|c|c|c|c|c|c|c|c|c|}
\hline \multirow{2}{*}{$\begin{array}{c}\text { Actual } S_{0} \\
(\mathrm{mg} / \mathrm{L})\end{array}$} & \multicolumn{4}{|c|}{ Logarithmic model } & \multicolumn{3}{|c|}{ First order kinetic model } & \multirow{2}{*}{$\begin{array}{l}\text { COD reduction } \\
\text { efficiencies (\%) }\end{array}$} \\
\hline & $S_{0}(\mathrm{mg} / \mathrm{L})$ & $k\left(d^{-1}\right)$ & $X_{0}(\mathrm{mg} / \mathrm{L})$ & Sum of error (\%) & $\mathrm{S}_{0}(\mathrm{mg} / \mathrm{L})$ & $k\left(d^{-1}\right)$ & Sum of error (\%) & \\
\hline 130 & 136.83 & $-0,451$ & 82.58 & 0.03 & 129.31 & -0.164 & 5.46 & 63 \\
\hline 250 & 251.71 & $-0,320$ & 94.48 & 0.01 & 230.35 & -0.140 & 7.69 & 38 \\
\hline 400 & 416.58 & $-0,216$ & 98.12 & 0.02 & 348.49 & -0.134 & 8.16 & 29 \\
\hline
\end{tabular}


Table 5. Parameters for Substrate - Growth Rate Kinetic Model

\begin{tabular}{lcc}
\hline \multicolumn{1}{c}{ Parameter } & Monod-Haldane & $\begin{array}{c}\text { Modified } \\
\text { Monod-Haldane }\end{array}$ \\
\hline$\mu_{\max }\left(\mathrm{d}^{-1}\right)$ & 0.44 & 0.03 \\
$K_{s}(\mathrm{mg} / \mathrm{L})$ & 58.85 & 7.443 \\
$K_{i}(\mathrm{mg} / \mathrm{L})$ & 78.22 & 332.840 \\
$K$ (constant) & - & 9.519 \\
$K_{I}(\mathrm{NTU})$ & - & 3.578 \\
$K_{I I}(\mathrm{NTU})$ & - & 179.472 \\
$R^{2}(\%)$ & 99.73 & 99.96 \\
Average Sum of error $(\%)$ & 10.88 & 6.01 \\
\hline
\end{tabular}

Table 6. Estimated Parameter of $R^{2}$ and d-index between Observed and Predicted Growth Rate Value on Monod-Haldane and Modified Monod-Haldane Model

\begin{tabular}{cccccccc}
\hline \multicolumn{3}{c}{ Monod-Haldane } & & \multicolumn{3}{c}{ Modified Monod-Haldane } \\
\cline { 1 - 3 } $\boldsymbol{\mu}_{\text {observed }}$ & $\boldsymbol{\mu}_{\text {predicted }}$ & $\mathbf{r}^{2}$ & $\mathbf{d}$ & & $\boldsymbol{\mu}_{\text {predicted }}$ & $\mathbf{r}^{\mathbf{2}}$ & $\mathbf{d}$ \\
\hline 0 & 0 & 0.996 & 1 & & 0.000 & 1 & 1 \\
0.12 & 0.120 & 0.999 & 0.729 & 0.120 & 1.000 & 1 \\
0.156 & 0.157 & 0.991 & 0.758 & 0.156 & 1.000 & 1 \\
0.165 & 0.161 & 0.824 & 0.724 & 0.165 & 0.998 & 1 \\
0.137 & 0.142 & 0.979 & 0.830 & & 0.137 & 0.993 & 1 \\
0.103 & 0.100 & 1.000 & 0.782 & 0.101 & 0.998 & 1 \\
0.07 & 0.071 & 0.996 & 0.747 & 0.068 & 0.999 & 1 \\
\hline
\end{tabular}

the turbidity acts as inhibitor at $\mathrm{K}_{\mathrm{I}} 3.578$ and $\mathrm{K}_{\mathrm{II}} 179.472$ NTU, respectively. While on modified Monod-Haldane model, the COD content inhibited the growth at $K_{i} 332.840 \mathrm{mg} / \mathrm{L}$, which is higher compared to Monod-Haldane model. Kamyab et al. [13] found that the growth of Chlamydomonas was quite slow when $500 \mathrm{mg} / \mathrm{L}$ and 1,000 mg/L COD of the POME was used as the substrate.

\subsection{Lipid and Carbohydrate Content of B. braunii}

For Table 7, the highest lipid (39.9\%), and carbohydrate (41.03\%) were recorded from $250 \mathrm{mg} / \mathrm{L}$ COD POME, while the biomass content from the control medium resulted higher lipid (62.3\%) and carbohydrate $(24.2 \%)$. It is stated that a higher temperature absorbed inside the cell than the surrounding water influenced a fatigue effect experienced by the algal cell walls. The higher differences of the temperature between inside and outside the cell, that was resulted from fast repeating frequency $(2.45 \mathrm{GHz})$, makes the walls more easily destroyed [41]. Previous research also reported that microwave irradiation on the hydrolysis of the algal biomass gave shorter time compared to conventional hydrolysis [42].

However, the biomass content was lower compared to previous research. Compared to another mixotrophic cultivation, the biomass of $B$. braunii was high in the presence of molasses as stated by Yeesang and Cheirsilp [43] .It seems that the presence of ammonium in the POME medium inhibited the growth of the $B$. braunii. This result was in agreement with Ruangsomboon [44] found that the addition of ammonium both in the form of urea and ammonium bicarbonate gave lower biomass production to $B$. braunii compared to nitrate. In addition, the high turbidity in the POME medium might also influenced the biomass production and the growth rate as explained above.

In this research, the carbohydrate productivity of $B$. braunii was slightly higher than lipid productivity. This result was in agreement with Ashokumar and Rengasamy [45] who reported the high carbohydrate productivity of $B$. braunii cultivated on modified Chu medium in open raceways system. In our research, the cultivation was carried out on $30^{\circ} \mathrm{C}$. The optimal temperature of $B$. braunii is $25^{\circ} \mathrm{C}$. It seems that the supraoptimal temperature inhibited the synthesis of intracellular lipids, and the algae tend to accumulate more carbohydrate as stock of energy [45]. However, the carbohydrate was also higher compared to control medium that was cultivated under autotrophic condition.

From GC/MS analysis, C16, C23, and C18 were found for fatty acid with the composition at $4.25,37.29$, and $2.10 \%$, respectively. The rich composition of hydrocarbon was consist of hexacosane $\left(\mathrm{C}_{26} \mathrm{H}_{54}\right)$ at $23.25 \%$, $n$ Dotriacontane $\left(\mathrm{C}_{32} \mathrm{H}_{66}\right)$ at $6.08 \%$, botryococcene $\left(\mathrm{C}_{34} \mathrm{H}_{58}\right)$ at $5.74 \%$, and n-eicosane $\left(\mathrm{C}_{20} \mathrm{H}_{42}\right)$ at $4.90 \%$. According to the analysis, it was not suitable for biodiesel source. However, high hydrocarbon composition is still promising for another fuel. Kitazato et al. [46] stated that the crude hydrocarbons of $B$. braunii can be converted to gasoline (60\% to $70 \%$ ), light cycle oil ( $10 \%$ to $15 \%)$, heavy cycle oil ( $2 \%$ to $8 \%$ ), and coke ( $5 \%$ to $10 \%$ ) by subjecting the crude oil to catalytic cracking. The lipid that extracted in the solvent can be burnt directly [12]. The high amount of carbohydrate from the biomass was also potential for other product such bioethanol and sugar fatty acid surfactant.

Table 7. Comparison of B. braunii Cultivated on Different Media

\begin{tabular}{lccccccc}
\hline \multicolumn{1}{c}{ Medium } & $\boldsymbol{X}$ & $\boldsymbol{L}$ & $\boldsymbol{C}$ & $\boldsymbol{P}_{\boldsymbol{x}}$ & $\boldsymbol{P}_{\boldsymbol{L}}$ & $\boldsymbol{P}_{\boldsymbol{c}}$ & Reference \\
\hline $250 \mathrm{mg} / \mathrm{L}$ COD POME & 0.429 & 39.9 & 41.03 & 44.18 & 17.63 & 18.11 & This Study \\
Control & 0.840 & 62.3 & 24.2 & 133 & 82.8 & -18 & This Study \\
15 g/L Molasses & 3.05 & 36.9 & NA & - & - & {$[43]$} \\
Modified Chu 13 Open raceways pond & 1.8 & 19 & 33 & 114 & 21.66 & 37.62 & {$[45]$} \\
\hline
\end{tabular}

Notes. $\mathrm{X}=$ dry biomass $(\mathrm{g} / \mathrm{L}), \mathrm{L}=$ lipid content $(\% \mathrm{w}), \mathrm{C}=$ carbohydrate content $(\% \mathrm{w}), \mathrm{P}_{\mathrm{x}}=$ biomass productivity $(\mathrm{mg} / \mathrm{L} / \mathrm{d}), \mathrm{P}_{\mathrm{L}}=$ lipid productivity $(\mathrm{mg} / \mathrm{L} / \mathrm{d}), P_{\mathrm{c}}=$ carbohydrate productivity $(\mathrm{mg} / \mathrm{L} / \mathrm{d})$. 


\section{Conclusions}

B. brauni was successfully cultivated on the low POME concentration. The Zwietering model was suitable to describe the growth. Lower initial COD substrate $(130 \mathrm{mg} / \mathrm{L})$, resulted higher consumption rate $\left(0.451 \mathrm{~d}^{-1}\right)$ and efficiency (63\%). The logarithmic kinetic model was suitable to predict the consumption rate of COD by $B$. braunii. The modified Monod Haldane model was also suitable to predict the optimum condition of the growth rate on the different POME concentration that influenced by turbidity $\left(\mathrm{K}_{\mathrm{I}} 3.578\right.$ and $\mathrm{K}_{\mathrm{II}} 179.472 \mathrm{NTU}$ ) and COD (Ki $\left.332.840 \mathrm{mg} / \mathrm{L}\right)$. The lipid (39.9\%), and carbohydrate $(41.03 \%)$ were found in the biomass that could be utilized as biofuel source.

\section{Acknowledgments}

The authors are pleased to acknowledge the LPPM Universitas Pembangunan Nasional (UPN) "Veteran” Yogyakarta for financial support in Research Cluster Project with contract number 2241/UN62/XI/2015. M. M. Azimatun Nur is pleased to acknowledge Indonesia Endowment Fund for Education (LPDP) for the support. The authors are also pleased to thank Yudha P. B. and R. Harvianto for the assistance.

\section{References}

1. FAOSTAT. Crops processed database [Internet]. Food and Agriculture Organization of the United Nations; c2016 [cited 19 October 2016]. Available from http://www.fao.org/faostat/en/\#data/QD/visualize.

2. BPS. Indonesian oil palm statistics. Jakarta: BPS Statistics Indonesia; 2015.

3. Otieno NE, Dai XP, De Barba D, et al. Palm oil production in malaysia: An analytical systems model for balancing economic prosperity, forest conservation and social welfare. Agr. Sci. 2016;7:55-69.

4. Saidu M, Yuzir A, Salim MR, Salmiati, Azman S, Abdullah N. Influence of palm oil mill effluent as inoculum on anaerobic digestion of cattle manure for biogas production. Bioresour. Technol. 2013;141:174-176.

5. Shak KPY, Wu TY. Optimized use of alum together with unmodified Cassia obtusifolia seed gum as a coagulant aid in treatment of palm oil mill effluent under natural $\mathrm{pH}$ of wastewater. Ind. Crops Prod. 2015;76:1169-1178.

6. Abdel-Raouf N, Al-Homaidan AA, Ibraheem IBM. Microalgae and wastewater treatment. Saudi J. Biol. Sci. 2012;19:257-275.

7. Delrue F, Alvarez-Diaz PD, Fon-Sing S, Fleury G, Sassi J-F. The environmental biorefinery: Using microalgae to remediate wastewater, a win-win paradigm. Energies 2016;132:1-19.

8. Resdi R, Jeng Shiun L, Hesam K, et al. Review of microalgae growth in palm oil mill effluent for lipid production. Clean Technol. Environ. Policy 2016;18:2347-2361.

9. Wai YC, Tau Chuan L, Pau LS, Joon CJ, Jo-Shu C, Duu-Jong L. Cultivation in wastewaters for energy: A microalgae platform.
Appl. Energ. 2016;179:609-625.

10. Wu TY, Mohammad AW, Lim SL, Lim PN, Hay JXW. Recent advances in the reuse of wastewaters for promoting sustainable development. In: Sharma SK, Sanghi R, eds. Wastewater reuse and management. Netherlands: Springer; 2013. p. 47-103.

11. Azimatun Nur MM, Hadiyanto H. Enhancement of Chlorella vulgaris biomass cultivated in POME medium as biofuel feedstock under mixotrophic conditions. J. Eng. Technol. Sci. 2015;47:487-497.

12. Banerjee A, Sharma R, Chisti Y, Banerjee A. Botryococcus braunii: A renewable source of hydrocarbons and other chemicals. Crit. Rev. Biotechnol. 2002;22:245-279.

13. Kamyab H, Din MFM, Keyvanfar A, et al. Efficiency of microalgae chlamydomonas on the removal of pollutants from palm oil mill effluent (POME). Energy Procedia 2015;75:2400-2408.

14. Silva NFP, Gonçalves AL, Moreira FC, et al. Towards sustainable microalgal biomass production by phycoremediation of a synthetic wastewater: A kinetic study. Algal Res. 2015;11:350-358.

15. Gani P, Sunar NM, Hazel M-P, Jamaian SS, Latiff AAA. Effects of different culture conditions on the phycoremediation efficiency of domestic wastewater. J. Environ. Chem. Eng. 2016;4:4744-4753.

16. Yamaguchi K, Nakano H, Murakami M, et al. Lipid composition of a green alga, Botryococcus braunii. Agr. Biol. Chem. 1987;51:493-498.

17. Alvarez-Diaz PD, Ruiz J, Arbib Z, Barragan J, Garrido-Perez C, Perales JA. Factorial analysis of biokinetic growth parameters and $\mathrm{CO}_{2}$ fixation rate Chlorella vulgaris and Botryococcus braunii in wastewater and synthetic medium. Desalin. Water Treat. 2014;52:4904-4914.

18. Myers JA, Curtis BS, Curtis WR. Improving accuracy of cell and chromophore concentration measurements using optical density. BMC Biophys. 2013;6:1-15.

19. SNI. Air dan air limbah - Bagian 22: Cara uji nilai permanganat secara titrimetri. 06-6989.22-2004. [cited 19 October 2016]. Available from: http://sisni.bsn.go.id/index.php?/sni_main/sni/ detail_sni/7001.

20. Bailley JF, Ollis DF. Biochemical engineering funadamentals. 2nd ed. Chennai: Tata McGraw Hill Publishers; 1986. p. 408-440.

21. Surendhiran D, Vijay M, Sivaprakash B, Surajunnisa A. Kinetic modeling of microalgal growth and lipid synthetic for biodiesel production. 3 Biotech. 2015;5:663-669.

22. Zwietering $\mathrm{MH}$, Jongenburger I, Rombouts FM, Riet $\mathrm{K}_{\text {VAN'T. }}$ Modelling of the bacterial curve. J. Appl. Environ. Microbiol. 1990;56:1875-1881.

23. Kayombo S, Mbwette TSA, Katima JHY, Jorgensen SE. Effects of substrate concentrations on the growth of heterotrophic bacteria and algae in secondary facultative ponds. Water Res. 2003;37:2937-2943.

24. Bougaran G, Rouxel C, Dubois N, et al. Enhancement of neutral lipid productivity in the microalgae Isochrysis affinis galbana (T-Iso) by a mutation-selection procedure. Biotechnol. Bioeng. 2012;109:2737-2745.

25. Gompertz B. On the nature of the function expressive of the law of human mortality, and on a new mode of determining the value of life contingencies. Philos. T. Roy. Soc. London 
1825;115:513-585.

26. Monod J. The growth of bacterial cultures. Annu. Rev. Microbiol. 1949;3:371-393.

27. Zhang XW, Zhang YM, Chen F. Kinetic models for phycocyanin production by high cell density mixotrophic culture of the microalga Spirulina platensis. J. Ind. Microbiol. Biotechnol. 1998;21:283-288.

28. Chojnacka K, Noworyta A. Evaluation of Spirulina sp. growth in photoautotrophic, heterotrophic and mixotrophic cultures. Enzyme Microb. Technol. 2004;34:461-465.

29. Mirzaie MAA, Kalbasi M, Ghobadian B, Mousavi SM. Kinetic modeling of mixotrophic growth of Chlorella vulgaris as a new feedstock for biolubricant. J. Appl. Phycol. 2016;28:2707-2717.

30. Thornton A, Weinhart T, Bokhove O, et al. Modeling and optimization of algae growth [Internet]. CASA Report 10-59. [cited 08 Sepember 2016]. Available from: www.doc.utwente.nl/ 75743/1/SecondSubmittedVersion.pdf.

31. Holliday CP, Rasmussen TC, Miller WP. Establishing the relationship between turbidity and total suspended sediment concentration. In: Proceedings of the 2003 Georgia Water Resources Conference, April 23-24 2003; University of Georgia: Athens, GA, USA.

32. Simkins S, Alexander M. Models for mineralization kinetics with the variables of substrate concentration and polulation density. Appl. Environ. Microbiol. 1984;47:1299-1306.

33. Teo CL, Idris A. Enhancing the various solvent extraction method via microwave irradiation for extraction of lipids from marine microalgae in biodiesel production. Bioresour. Technol. 2014;171:477-481.

34. Dubois M, Gilles KA, Hamilton JK, Rebers PA, Smith F. Colorimetric method for determination of sugar and related substances. Anal. Chem. 1956;28:350-356.

35. Martinez-Guerra E, Veera Gnaneswar G, Andro M, William H, Rafael H. Extractive-transesterification of algal lipids under microwave irradiation with hexane as solvent. Bioresour. Technol. 2014;156:240-247.
36. Sahu A, Imran P, Deepti J, et al. Fatty acids as biomarkers of microalgae. Phytochemistry 2013;89:53-58.

37. Nakagawa S, Schielzeth H. A general and simple method for obtaining $\mathrm{R}^{2}$ from generalized linear mixed-effects models. Methods Ecol. Evol. 2013;4:133-142.

38. Willmott CJ. On the validation of models. Phys. Geograph. 1981;2:184-194.

39. Hadiyanto H, Azimatun Nur MM. Lipid extraction of microalgae Chlorella sp. cultivated in palm oil mill effluent (POME) medium. World Appl. Sci. J. 2014;31:959-967.

40. Budiman PM, Wu TY, Ramanan RN, Hay JXW. Treatment and reuse of effluents from palm oil, pulp, and paper mills as a combined substrate by using purple nonsulfur bacteria. Ind Eng. Chem. Res. 2014;53:14921-14931.

41. Avinesh RB, Adarsha G, Colin JB, Munish P. Evaluation and comparison of algal cell disruption methods: Microwave, waterbath, blender, ultrasonic and laser treatment. Mar. Drugs 2015;13:5111-5127.

42. Azimatun Nur MM, Dedy K, Setyoningrum TM, Budiaman IGS. Utilization of microalgae cultivated in palm oil mill wastewater to produce lipid and carbohydrate by employing microwave-assisted irradiation. Recent Innovation Chem. Eng. 2016;9:107-116.

43. Yeesang C, Cheirsilp B. Low-cost production of green microalga Botryococcus braunii biomass with high lipid content through mixotrophic and photoautotrophic cultivation. Appl. Biochem. Biotechnol. 2014;174:116-129.

44. Ruangsombong S. Effects of different media and nitrogen sources and levels on growth and lipid of green microalga Botryococcus braunii KMTL and its biodiesel properties based on fatty acid composition. Bioresour. Technol. 2015;191:377-384.

45. Ashokumar V, Rengasamy R. Mass culture of Botryococcus braunii Kutz. under open raceway pond for biofuel production. Bioresour. Technol. 2012;104:394-399.

46. Kitazato H, Asaoka S, Iwamoto H. Catalytic cracking of hydrocarbons from microalgae. J. JPN. Petrol. Inst. 1989;32:28-34. 